\title{
COMPETENCY LEVEL OF ENGINEERING GRADUATES AND QUALITY OF ENGINEERING EDUCATION IN NEPAL
}

\author{
Er. Bharat R. Pahari, Ph.D. \\ Associate Professor, Civil Engineering Department, Pulchowk Campus, Institute of Engineering, Tribhuvan University \\ Email: bharatpahari@hotmail.com
}

\begin{abstract}
This study is the part of the outcome of the research work on quality of engineering education in Nepal. Some 246 respondents among the stakeholders of engineering education were referred in this research. In the course of time, the pace of development of the engineering education is appreciable. However, there are the voices from different stakeholders that the existing level of graduating engineers from Nepal are not meeting the standard demanded by the market. In the course of time, pressure has been intensified to respond this in prevailing education system. This has developed concern over the competency parameters as the tools of quality in engineering higher education. This study, therefore is an attempt to explore the competency level of the graduating engineers of Nepal. In this study, some prominent competency parameters influencing quality of engineering education were identified.
\end{abstract}

Key words: competency, quality, engineering education, graduating engineers etc.

\section{INTRODUCTION}

Over the past two decades, the engineering higher education system in Nepal has successfully concentrated on production of engineers and on developing infrastructures for engineering higher education. The first batch of engineers enrolled were 22 in Institute of Engineering and passed numbers were 17 in 1983 and this has increased to about 2014 in 2003 (IOE, 2005 \&UGC, 2004) annual intake from 28 engineering colleges so far. However, there are the voices from policy makers, employers and faculties that the existing level of graduating engineers from Nepal are not meeting the standard demanded by the market (Shrestha, 2006). In the course of time, pressure has been intensified to respond this in prevailing education system. This has developed concern over the equity, quality and competence in engineering higher education.

The globalisation has been widespread now. Nepal has also entered into the world trade organisation. The effect of globalisation is now appearing in Nepal. The quality and competence are the prime issues now. Unless, Nepalese engineers prove to be capable and competence in the global market, the situation is going to be much harder for them now and after (Paudel, 2006).

The world is expanding to a global village. A country can not survive in a closed boundary as before. The education, more precisely the engineering higher education, should be able to load individual a depth knowledge and skill that makes people capable and competent to cope with confronting issues. The accreditation Board for Engineering and Technology has prescribed 11 outcomes essential as a body of knowledge (ASCE, 2004). These are the basis for the entry in the global market. The outcomes of Nepalese Engineering Colleges are found to be not meeting these standards (Suwal, 2006). 


\section{COMPETENCY PARAMETERS}

After going through the literatures, representative competency parameters were developed. Those parameters were further grouped into four categories, namely; basic knowledge and skill, specific professional capacity, understanding society and social phenomena, management and leadership etc. Every cluster consisted of competency statement as follows;

\section{Basic knowledge and skil}

$\mathrm{P}_{1}$ Communicate orally

$\mathrm{P}_{2}$ Communicate through written documents

$\mathrm{P}_{3}$ Present technical information using audiovisuals

$\mathrm{P}_{4}$ Communicate through graphical means

$\mathrm{P}_{5}$ Communicate through electronic means;(e-mail, internet)

$\mathrm{P}_{6}$ Apply knowledge of mathematics, science and engineering

$\mathrm{P}_{7}$ Demonstrate full responsibility for own actions and decisions

$\mathrm{P}_{8}$ Design \& conduct research/ feasibility studies for specific projects

$\mathrm{P}_{9}$ Design \& conduct laboratory tests (experiments)

$\mathrm{P}_{10}$ Interpret data and prepare documents

Specific Professional Capacity

$\mathrm{P}_{11}$ Design a system, component, or process to meet desired requirements and needs

$\mathrm{P}_{12}$ Conduct and coordinate quality control and quality assurance procedures

$P_{13}$ Analyze properties of engineering materials to be used in engineering design

$\mathrm{P}_{14}$ Identify, formulate, and solve engineering problems

$\mathrm{P}_{15}$ Use the techniques, skills, and modern engineering tools necessary for engineering practice

$\mathrm{P}_{16}$ Understand \& practice professional and ethical responsibility

$\mathrm{P}_{17}$ Practice the principles of sustainable development in engineering design

$\mathrm{P}_{18}$ Produce effective documentation of the engineering design

$\mathrm{P}_{19}$ Practice the principles of sustainable development in engineering design

$\mathrm{P}_{20}$ Evaluate the impact of engineering design in the society

Understanding society and social phenomena

$\mathrm{P}_{21}$ Understand the impact of engineering solutions in a global and societal context

$\mathrm{P}_{22}$ Analyze the impact of the engineering service on society

$\mathrm{P}_{23}$ Demonstrate understanding of socio-cultural context of the country

$\mathrm{P}_{24}$ Demonstrate understanding of the political and legal context regarding engineering practices

$\mathrm{P}_{25}$ Demonstrate understanding of democratic practices and community participation

\section{Management and Leadership}

$\mathrm{P}_{26}$ Analyze economic and financial consequences of engineering projects

$\mathrm{P}_{27}$ Coordinate smooth operation of the projects using basic principles of management

$\mathrm{P}_{28}$ Lead for system development \& improvement by making projects technically sound \& viable as a leader \& as a member

$\mathrm{P}_{29}$ Assess effectiveness of the projects in relation with established standard understanding interrelationship between society, technology and environment 
Attempt was made to explore the existing level of competency of the engineering graduates in the entry level engineering professional practice. The responses on the desired level of competency were also identified.

\section{THE RESPONDENTS}

Stakeholders' response is important to know the state of condition of competency level of graduating engineers. The observations and expectations of respondents are the guidelines to measure the performances and also to explore new directions.

Nepalese educational policy makers and employers are the principal sources of information to find the level of competency of engineers. Besides, Faculties and students are other important sources.

Based on organisational affiliation and the occupational status, four major groups of respondents were identified.

- Policy makers who are directly involved in the formulation of engineering policy of the country. This group includes authorities of; universities and campuses, Nepal Engineering Council, ministry of education and sports etc.

- Faculties who are directly or indirectly involved in the teaching of engineering education and play significance role in policy implementation. The group of faculties is represented by the professors, associate professors and senior lecturers in the universities and colleges who are delivering engineering education. Priorities have been given to the permanent faculties in the colleges.

- Students who are studying in the final year of bachelor level of different engineering disciplines. The group of student is represented by the students studying in different discipline of engineering in bachelor level from different universities and colleges. The students in the final year of all discipline are taken as the representative students for this study.

- Employers who can influence engineering education policy and play significance role in the employment to the engineering graduates. The group of employer is represented by consultants and government departments. Though, engineers are employed in wider span of areas, this study is focused in the major sectors, namely; engineering consulting firms in private sector and government departments in public sector.

\section{ANALYSIS OF THE RESPONSES}

Almost all respondents rated fair to good to the statement for the existing level of competency, whereas, they have rated higher level for the desired level of competency. The trends of rating on individual statements and the category were found similar.

There were four categories in the competency requirements. Those categories are; basic knowledge and skill, specific professional capacity, understanding society and social phenomena and management and leadership. The rating of the sum of the statements in the categories is presented in the tables below;

\begin{tabular}{lllll}
\multicolumn{4}{l}{ Basic Knowledge and Skill } \\
& \multicolumn{2}{c}{ Existing level } & \multicolumn{2}{l}{ Desired level } \\
& Percent & Frequency & Percent & Frequency \\
\hline NA & 2 & 4 & 0 & 0 \\
P & 8 & 18 & 0 & 1 \\
F & 27 & 61 & 1 & 3 \\
G & 39 & 90 & 10 & 24 \\
VG & 20 & 45 & 44 & 101 \\
E & 5 & 11 & 44 & 101 \\
Total & 100 & 246 & 100 & 246 \\
\hline
\end{tabular}

(NA=not applicable, $\mathrm{P}=$ poor, $\mathrm{F}=$ fair, $\mathrm{G}=$ good, $\mathrm{VG}=$ very good, $\mathrm{E}=$ excellent) 
Above table indicated the response rate of the respondents on existing and desired level of competency in basic knowledge and skill. This indicates that about 76 percent respondents (rating neutral and below) thought the existing level of basic knowledge and skill of the engineering graduates is not satisfactory.

Similarly, the table showed that 88 percent of the respondents either desired to the very good level or to the excellent level of competency in basic knowledge and skill. This indicates that respondents highly considered basic knowledge and skill parameter. As the rating of desired level is very high in compare to the existing level, it indicated the necessity of improvement in this area.

\begin{tabular}{lllll}
\multicolumn{5}{c}{ Specific Professional Capacity } \\
& \multicolumn{2}{c}{ Existing level } & \multicolumn{2}{l}{ Desired level } \\
& Percent & Frequency & Percent & Frequency \\
\hline NA & 3 & 6 & 0 & 0 \\
P & 13 & 31 & 1 & 2 \\
F & 33 & 75 & 2 & 4 \\
G & 35 & 79 & 9 & 21 \\
VG & 13 & 31 & 47 & 108 \\
E & 3 & 8 & 41 & 95 \\
Total & 100 & 246 & 100 & 246 \\
\hline
\end{tabular}

(NA=not applicable, $\mathrm{P}=$ poor, $\mathrm{F}=$ fair, $\mathrm{G}=$ good,

$\mathrm{VG}=$ very good, $\mathrm{E}=$ excellent)

Above table indicated the response rates on existing and desired level in specific professional capacity. Data indicates that about 84 percent respondents think the existing level of specific professional capacity is unsatisfactory. Similarly, in the table, respondents considered the specific professional capacity in professional areas as important component for the quality of engineering practice. Data showed that 88percent of the respondents either desired to the very good level or to the excellent level. As the rating of desired level is very high in compare to the existing level, it indicated the necessity of improvement in this area.

\begin{tabular}{lllll}
\multicolumn{5}{c}{ Understanding Society and Social Phenomena } \\
\hline \multicolumn{2}{c}{ Existing level } & \multicolumn{2}{c}{ Desired level } \\
\hline NA & 2 & 5 & 0 & 0 \\
P & 13 & 30 & 1 & 2 \\
F & 37 & 96 & 3 & 8 \\
G & 31 & 71 & 13 & 29 \\
VG & 13 & 29 & 45 & 110 \\
E & 4 & 9 & 38 & 92 \\
Total & 100 & 246 & 100 & 246 \\
\hline
\end{tabular}

(NA=not applicable, $\mathrm{P}=$ poor, $\mathrm{F}=$ fair, $\mathrm{G}=$ good, VG=very good, E=excellent)

Above table indicated the response rates on understanding society and social phenomena. Data indicated that about 83 percent respondents think the existing level of understanding society and social phenomena is unsatisfactory.

Similarly, above table showed that respondents considered the capacity of understanding society and social phenomena in professional areas as important component for the quality of engineering practice. Data showed that 83 percent of the respondents either desired to the very good level or to the excellent level. As the rating of desired level is very high in compare to the existing level, it indicated the necessity of improvement in this area.

\begin{tabular}{lllll}
\multicolumn{5}{c}{ Management and Leadership } \\
\hline & \multicolumn{2}{c}{ Peristing level } & \multicolumn{2}{c}{ Desired level } \\
& Percent & Frequency & Percent & Frequency \\
\hline NA & 2 & 4 & 0 & 0 \\
P & 15 & 34 & 1 & 3 \\
F & 36 & 83 & 4 & 8 \\
G & 32 & 74 & 12 & 27 \\
VG & 11 & 26 & 46 & 105 \\
E & 4 & 9 & 38 & 87 \\
Total & 100 & 246 & 100 & 246 \\
\hline
\end{tabular}


(NA=not applicable, $\mathrm{P}=$ poor, $\mathrm{F}=$ fair, $\mathrm{G}=$ good, $\mathrm{VG}=$ =very good, $\mathrm{E}=$ excellent)

Above table indicated the response rates on management and leadership. The data indicated that about 85 percent respondents think the existing level of management and leadership capacity is unsatisfactory.

Similarly, above table showed that respondents considered the management and leadership in professional areas as important component for the quality of engineering practice. Data showed that 84 percent of the respondents either desired to the very good level or to the excellent level. As the rating of desired level is very high in compare to the existing level, it indicated the necessity of improvement in this area.

The values of the above tables were compared and presented in the figure below. According to which respondents of 37, 20, 18 and 18 percent opined very good to the existing level for basic knowledge and skill, specific professional capacity, understanding society \& social phenomena and management \& leadership respectively. However, the respondents of 63, 5060 and 60 percent rated unsatisfactory for those competency parameters respectively. Almost 90 percent respondents rated the desired level for competency parameters to the higher limit demanding the improvement in the existing level of capacity. The figure reveals that very small numbers of respondents opined the existing level of competency is in the satisfactory level and largest numbers responded in unsatisfactory and almost 90 percent desired to higher level of competency in all parameters. This indicates strong opinions for the improvement in the capacity of the graduating engineers.

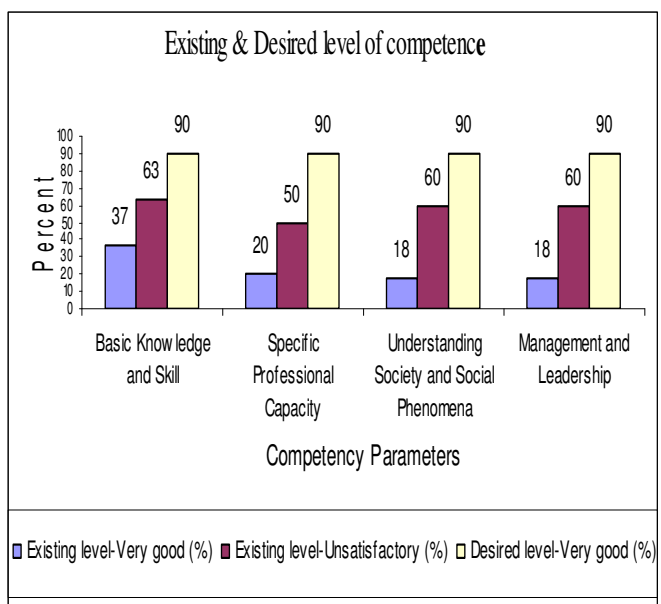

\section{FINDINGS}

Analysis of variance for each of the 30 statements in four categories was calculated to determine whether there were statistically significant differences in the perceptions of respondents- faculty, student, policy maker and employer. Following the five point Likert rating, ranking was made in such a way that those statements with; not applicable, poor and fair $(\mathrm{N}, 1 \& 2)$ were marked as low. Others with good level (3) were marked as middle and those statements with; very good and excellent levels (4 \& 5) were marked as high level. The statements with middle marking were not included in the table as they do not influence the analysis. In the table, percent of frequencies are taken for the analysis.

The table was sorted on the basis of existing and desired level in the high and low marking. 
Basic Knowledge and Skill

\begin{tabular}{lllll}
\hline Items & Existing & \multicolumn{3}{c}{ Desired } \\
& high & low & high & low \\
\hline p1 & 22.2 & 27.4 & 88.3 & 2.6 \\
p2 & 30.9 & 25.2 & 88.3 & 1.7 \\
p3 & 17.8 & 40.9 & 85.2 & 1.7 \\
p4 & 21.3 & 43.9 & 84.8 & 2.6 \\
p5 & 37.4 & 28.7 & 90.4 & 0.9 \\
p6 & 35.7 & 19.6 & 89.1 & 0.4 \\
p7 & 24.8 & 36.1 & 90.0 & 1.3 \\
p8 & 16.5 & 49.6 & 88.3 & 2.2 \\
p9 & 17.8 & 43.9 & 86.1 & 2.6 \\
p10 & 21.3 & 47.4 & 88.3 & 3.5 \\
\hline
\end{tabular}

The table illustrates the ranking of the respondents on existing and desired level of basic knowledge and skill. Among the total respondents, only 37 percent or less numbers of respondents agreed on the existing level of basic knowledge and skill of graduating engineers to be either very good or excellent, whereas, 67 percent opined the existing level either fair or poor.

Whereas, 85 percent and above respondents agreed the desired level of basic knowledge and skill of the graduating engineers to be in the level of either very good or excellent.

Highest Marking on Basic Knowledge and Skill (Existing Level)

\begin{tabular}{ll}
\hline Items & Statements \\
\hline p5 & $\begin{array}{l}\text { Communicate through electronic } \\
\text { means;(e-mail, internet) }\end{array}$ \\
p6 & $\begin{array}{l}\text { Apply knowledge of mathematics, science } \\
\text { and engineering }\end{array}$ \\
p2 & $\begin{array}{l}\text { Communicate through written documents } \\
\text { p7 }\end{array}$ \\
p1 & $\begin{array}{l}\text { Demonstrate full responsibility for own } \\
\text { Communicate orally }\end{array}$ \\
p4 & $\begin{array}{l}\text { Communicate through graphical means } \\
\text { p10 }\end{array}$ \\
Interpret data and prepare documents \\
P3 & $\begin{array}{l}\text { Present technical information using } \\
\text { audiovisuals }\end{array}$ \\
P9 & $\begin{array}{l}\text { Design \& conduct laboratory tests } \\
\text { (experiments) }\end{array}$
\end{tabular}
Design \& conduct research/ feasibility
studies for specific projects

The table illustrates the statements in category basic knowledge and skill in the order of highest marking on existing level of graduating engineers. This indicates that engineers have satisfactory level in communication skill through electronic means and poorest in the design and conducting of research studies for specific projects.

Highest Marking on Basic Knowledge and Skill (Desired level)

\begin{tabular}{|c|c|}
\hline Items & Statements \\
\hline p5 & $\begin{array}{l}\text { Communicate through electronic means;(e- } \\
\text { mail, internet) }\end{array}$ \\
\hline p7 & $\begin{array}{l}\text { Demonstrate full responsibility for own } \\
\text { actions and decisions }\end{array}$ \\
\hline p6 & $\begin{array}{l}\text { Apply knowledge of mathematics, science } \\
\text { and engineering }\end{array}$ \\
\hline $\mathrm{p} 1$ & Communicate orally \\
\hline $\mathrm{p} 2$ & Communicate through written documents \\
\hline p8 & $\begin{array}{l}\text { Design \& conduct research/ feasibility } \\
\text { studies for specific projects }\end{array}$ \\
\hline p10 & Interpret data and prepare documents \\
\hline p9 & $\begin{array}{l}\text { Design \& conduct laboratory tests } \\
\text { (experiments) }\end{array}$ \\
\hline p3 & $\begin{array}{l}\text { Present technical information using } \\
\text { audiovisuals }\end{array}$ \\
\hline $\mathrm{p} 4$ & Communicate through graphical means \\
\hline \multicolumn{2}{|c|}{$\begin{array}{l}\text { The table illustrates the statements in } \\
\text { category basic knowledge and skill in the } \\
\text { order of highest marking on desired level of } \\
\text { graduating engineers. This indicates that } \\
\text { engineers' capacity, though exists in } \\
\text { satisfactory level, desired to have excellent } \\
\text { communication skill through electronic } \\
\text { means and ranked the lowest to the desired } \\
\text { level in communication skill through } \\
\text { graphical means. }\end{array}$} \\
\hline
\end{tabular}




\begin{tabular}{lllll}
\multicolumn{3}{l}{ Specific Professional Capacity } \\
\hline Items & Existing & \multicolumn{3}{l}{ Desired } \\
& high & low & high & low \\
\hline p11 & 14.3 & 47.8 & 83.9 & 3.0 \\
p12 & 13.9 & 46.5 & 85.2 & 3.0 \\
p13 & 17.8 & 49.1 & 85.7 & 3.0 \\
p14 & 19.6 & 50.0 & 90.4 & 2.2 \\
p15 & 19.6 & 49.1 & 90.0 & 2.2 \\
p16 & 20.9 & 46.5 & 89.6 & 2.6 \\
p17 & 16.5 & 54.3 & 88.3 & 4.8 \\
p18 & 13.5 & 44.8 & 87.4 & 2.2 \\
p19 & 12.2 & 50.0 & 90.4 & 2.6 \\
p20 & 18.3 & 50.4 & 90.0 & 2.2 \\
\hline
\end{tabular}

The table illustrates the ranking of the respondents on existing and desired level of specific professional capacity. Among the total respondents, only 20 percent or less numbers of respondents agreed on the existing level of specific professional capacity of graduating engineers to be either very good or excellent, whereas, 80 percent opined the existing level either fair or poor.

Whereas, 85 percent and above respondents agreed the desired level of specific professional capacity of the graduating engineers to be in the level of either very good or excellent.

\section{Highest Marking on Specific Professional Capacity (Existing Level)

\begin{tabular}{ll}
\hline Items & Statements \\
\hline P16 & $\begin{array}{l}\text { Understand \& practice professional and } \\
\text { ethical responsibility }\end{array}$ \\
P14 & $\begin{array}{l}\text { Identify, formulate, and solve engineering } \\
\text { problems }\end{array}$ \\
P15 & $\begin{array}{l}\text { Use the techniques, skills, \& modern tools } \\
\text { necessary for engineering practice }\end{array}$ \\
P20 & $\begin{array}{l}\text { Evaluate the impact of engineering design } \\
\text { in the society }\end{array}$ \\
P13 & $\begin{array}{l}\text { Analyze properties of engineering } \\
\text { materials to be used in engineering design }\end{array}$ \\
P17 & $\begin{array}{l}\text { Practice the principles of sustainable } \\
\text { development in engineering design }\end{array}$
\end{tabular}

\author{
P11 Design a system, component, or process to \\ meet desired requirements and needs \\ P12 Conduct and coordinate quality control and \\ quality assurance procedures \\ P18 Produce effective documentation of the \\ engineering design \\ P19 Practice the principles of sustainable \\ development in engineering design
}

The table illustrates the statements in category specific professional capacity in the order of highest marking on existing level of graduating engineers. This indicates that engineers have satisfactory level in understanding \& practice professional and ethical responsibility and poorest in the practicing of the principles of sustainable development in engineering design.

\section{Highest Marking on Specific Professional Capacity (Desired Level)}

\begin{tabular}{|c|c|}
\hline Items & Statements \\
\hline P14 & $\begin{array}{l}\text { Identify, formulate, and solve engineering } \\
\text { problems }\end{array}$ \\
\hline P19 & $\begin{array}{l}\text { Practice the principles of sustainable } \\
\text { development in engineering design }\end{array}$ \\
\hline P15 & $\begin{array}{l}\text { Use the techniques, skills, \& modern tools } \\
\text { necessary for engineering practice }\end{array}$ \\
\hline $\mathrm{P} 20$ & $\begin{array}{l}\text { Evaluate the impact of engineering design in } \\
\text { the society }\end{array}$ \\
\hline P16 & $\begin{array}{l}\text { Understand \& practice professional and } \\
\text { ethical responsibility }\end{array}$ \\
\hline P17 & $\begin{array}{l}\text { Practice the principles of sustainable } \\
\text { development in engineering design }\end{array}$ \\
\hline P18 & $\begin{array}{l}\text { Produce effective documentation of the } \\
\text { engineering design }\end{array}$ \\
\hline P13 & $\begin{array}{l}\text { Analyze properties of engineering materials } \\
\text { to be used in engineering design }\end{array}$ \\
\hline $\mathrm{P} 12$ & $\begin{array}{l}\text { Conduct and coordinate quality control and } \\
\text { quality assurance procedures }\end{array}$ \\
\hline P11 & $\begin{array}{l}\text { Design a system, component, or process to } \\
\text { meet desired requirements and needs }\end{array}$ \\
\hline
\end{tabular}

The table illustrates the statements in category specific professional capacity in the order of highest marking on desired level of graduating engineers. This indicates that 
engineers' capacity, though exists in satisfactory level, desired to have excellent skill in Identify, formulate, and solve engineering problems and ranked the lowest to the desired level to the skill of designing a system, component, or process to meet desired requirements and needs.

Understanding Society and Social Phenomena

\begin{tabular}{lllll}
\hline Items & Existing & & Desired \\
\hline & high & low & high & low \\
p21 & 18.7 & 50.4 & 87.0 & 2.6 \\
p22 & 17.8 & 52.2 & 87.4 & 2.6 \\
p23 & 12.6 & 57.8 & 81.3 & 3.9 \\
p24 & 15.7 & 53.9 & 79.6 & 4.8 \\
p25 & 18.3 & 49.1 & 81.3 & 3.9 \\
\hline
\end{tabular}

The table illustrates the ranking of the respondents on existing and desired level of understanding society and social phenomena. Among the total respondents, only 18 percent or less numbers of respondents agreed on the existing level of understanding society and social phenomena of graduating engineers to be either very good or excellent, whereas, 82 percent opined the existing level either fair or poor.

Whereas, 79 percent and above respondents agreed the desired level of understanding society and social phenomena of the graduating engineers to be in the level of either very good or excellent.

Highest Marking on Understanding Society \& Social Phenomena (Existing Level)

\begin{tabular}{ll}
\hline Items & Statements \\
\hline p21 & $\begin{array}{l}\text { Understand the impact of engineering } \\
\text { solutions in a global and societal context }\end{array}$ \\
p25 & $\begin{array}{l}\text { Demonstrate understanding of democratic } \\
\text { practices and community participation }\end{array}$ \\
p22 & $\begin{array}{l}\text { Analyze the impact of the engineering } \\
\text { service on society }\end{array}$ \\
p24 & $\begin{array}{l}\text { Demonstrate understanding of democratic } \\
\text { practices and community participation }\end{array}$ \\
p23 & $\begin{array}{l}\text { Demonstrate understanding of socio- } \\
\text { cultural context of the country }\end{array}$ \\
\hline
\end{tabular}

The table illustrates the statements in category understanding society and social phenomena in the order of highest marking on existing level of graduating engineers. This indicates that engineers have satisfactory level in understand the impact of engineering solutions in a global and societal context and poorest in demonstrating the understanding of socio-cultural context of the country.

\begin{tabular}{ll}
\multicolumn{2}{l}{$\begin{array}{l}\text { Highest Marking on Understanding Society and } \\
\text { Social Phenomena (Desired Level) }\end{array}$} \\
\hline Items & Statements \\
\hline p22 & $\begin{array}{l}\text { Analyze the impact of the engineering } \\
\text { service on society }\end{array}$ \\
p21 & $\begin{array}{l}\text { Understand the impact of engineering } \\
\text { solutions in a global and societal context }\end{array}$ \\
p23 & $\begin{array}{l}\text { Demonstrate understanding of socio- } \\
\text { cultural context of the country }\end{array}$ \\
p25 & $\begin{array}{l}\text { Demonstrate understanding of democratic } \\
\text { practices and community participation }\end{array}$ \\
p24 & $\begin{array}{l}\text { Demonstrate understanding of democratic } \\
\text { practices and community participation }\end{array}$ \\
\hline
\end{tabular}

The table illustrates the statements in category understanding society and social phenomena in the order of highest marking on desired level of graduating engineers. This indicates that engineers' capacity, though exists in satisfactory level, desired to have excellent skill in analyzing the impact of the engineering service on society and ranked the lowest to the desired level to the skill of demonstrating the understanding of democratic practices and community participation.

\begin{tabular}{lllll}
\multicolumn{2}{l}{ Management and Leadership } \\
\cline { 1 - 2 } Items & Existing & & \multicolumn{3}{l}{$\begin{array}{l}\text { Desire } \\
\text { d }\end{array}$} \\
\cline { 1 - 2 } p26 & high & low & high & low \\
p27 & 18.3 & 47.0 & 87.8 & 3.9 \\
p28 & 14.3 & 51.7 & 85.7 & 3.9 \\
p29 & 15.7 & 54.3 & 83.5 & 4.3 \\
p30 & 12.6 & 54.8 & 81.3 & 4.8 \\
\hline
\end{tabular}


The table illustrates the ranking of the respondents on existing and desired level of management and leadership. Among the total respondents, only 18 percent or less numbers of respondents agreed on the existing level of management and leadership of graduating engineers to be either very good or excellent, whereas, 82 percent opined the existing level either fair or poor.

Whereas, 78 percent and above respondents agreed the desired level of management and leadership of the graduating engineers to be in the level of either very good or excellent.

\begin{tabular}{ll}
$\begin{array}{l}\text { Highest Marking on Management and Leadership } \\
\text { (Existing Level) }\end{array}$ \\
\hline Items & Statements \\
\hline p26 & $\begin{array}{l}\text { Analyze economic and financial } \\
\text { consequences of engineering projects } \\
\text { Lead for system development \& } \\
\text { improvement by making projects } \\
\text { technically sound \& viable as a leader \& as } \\
\text { a member }\end{array}$ \\
p27 & $\begin{array}{l}\text { Coordinate smooth operation of the } \\
\text { projects using basic principles of } \\
\text { management }\end{array}$ \\
p30 & $\begin{array}{l}\text { Adhere with contextual issues governing } \\
\text { management of projects }\end{array}$ \\
& $\begin{array}{l}\text { Assess effectiveness of the projects in } \\
\text { relation with established standard } \\
\text { understanding interrelationship between } \\
\text { society, technology and environment }\end{array}$ \\
\hline
\end{tabular}

The table illustrates the statements in category management and leadership in the order of highest marking on existing level of graduating engineers. This indicates that engineers have satisfactory level in analyzing economic and financial consequences of engineering projects and poorest in assess effectiveness of the projects in relation with established standard understanding interrelationship between society, technology and environment.

\begin{tabular}{ll}
$\begin{array}{l}\text { Highest Marking on Management and Leadership } \\
\text { (Desired Level) }\end{array}$ \\
\hline Items & Statements \\
\hline p26 & $\begin{array}{l}\text { Analyze economic and financial } \\
\text { consequences of engineering projects }\end{array}$ \\
p27 & $\begin{array}{l}\text { Coordinate smooth operation of the projects } \\
\text { using basic principles of management }\end{array}$ \\
p28 & $\begin{array}{l}\text { Lead for system development \& } \\
\text { improvement by making projects } \\
\text { technically sound \& viable as a leader \& as }\end{array}$ \\
a member
\end{tabular}

The table illustrates the statements in category management and leadership in the order of highest marking on desired level of graduating engineers. This indicates that engineers' capacity, though exists in satisfactory level, desired to have excellent skill in analyzing economic and financial consequences of engineering projects and ranked the lowest to the desired level to the skill of adhering with contextual issues governing management of projects.

While selecting lowest ranking of the statements in the competency area, some interesting picture appeared on the surface. More than 50 percent respondents responded that present graduating engineers have low level of knowledge in understanding sociocultural context of the country. They are also weak in project management and leadership and also weak in understanding sustainable development.

The most prominent statement in the desired level of competency of graduating engineer with high rating were taken as one third numbers of statements from above table. About 90 percent respondents had given highest priority for these statements. The first ranking statement is concerned with electronic communication capacity. The 
second and third statements are concerned with specific professional capacity. Among the high ranked statements five numbers are related with communication skill. This is an indicative that basic knowledge and skill, though exists in satisfactory level, need to be further developed. Very insignificant numbers of respondents ranked on the lower side of the desired level of competency.

\section{CONCLUSIONS}

There were 30 statements related to the professional competencies and were grouped into four major categories; basic knowledge and skill, specific professional capacity, understanding society and social phenomena, management $\&$ leadership etc. and the rating values for these categories came similar to the trend in the individual statements. The mean values were analyzed to find the deviations in opinions among the respondents on competency parameters. The mean values of existing level were found smaller than desired level indicating emphasis of the respondents on the capacity improvement of the graduating engineers.

The rating of the students in the competency parameters were in the higher side for both existing and desired level compare to other respondents, but the trend was found similar. Though the trend was similar, there were significant differences in the opinions of students with other respondents. The rating of employer and policy makers were in close proximity and to the lower side than students and faculties for both existing and desired level.

The existing level of the graduating engineers was rated to the average range stating satisfactory level in almost all the statements related with competency parameters, whereas, the desired level of graduating engineers was rated very high. The respondents were expecting higher capacity in competency parameters.
Despite the fact that the respondents marked all the statements as highly considerable, the desired outstanding statements 20 percent from above have been marked as most prominent statements in all categories as follows;

Basic knowledge and skills

- Communication through e-mail, internet etc.

- Demonstrate full responsibility for own actions and decisions.

- $\quad$ Specific professional capacity

- Identify, formulate, and solve engineering problems

- Practicing the principles of sustainable development in engineering design

- Understanding Society \& Social Phenomena

- Analyzing the impact of the engineering service on society

- Management and leadership

- Analyzing economic and financial consequences of engineering projects

\section{REFERENCES}

[1] ASCE, (2004), Civil Engineering Body of Knowledge for 21st Century, preparing the civil engineers for the future, American society of civil Engineers,

[2] IOE, (2005), Annual Report of the Institute of Engineering, Tribhuvan University, Pulchowk, Lalitpur, 2005.

[3] Pahari, B.R. (2006), Engineering Education: Quality and Competency Perspective, a seminar paper presented in the seminar organised in Institute of Engineering, Pulchowk on 31st January 2006 by Associate professor Bharat Pahari

[4] Paudel, R.K., (2006), Priorities and Strategies of Engineering education: National and Global perspective, A 
seminar paper presented in a seminar organised in Institute of engineering in January 31, 2006 by the Dean of the IOE Prof. Dr. Ram Krishna Paudel.

[5] Shrestha, P.B., (2006), Quality Assurance Strategy, Policy framework and guidelines for the institutionalisation of a quality assurance system in the engineering education and training sector in Nepal, A comment paper presented in the seminar organised in IOE, Pulchowk by Prof. Dr. Pramod B. Shrestha on 31 January 2006.
[6] Suwal, (2006), The quality of Engineering education in Nepal, a seminar paper presented by Dr. Rajan Suwal, organised in Institute of engineering in January 31, 2006.

[7] UGC, (2004), Annual Report-2003/2004 of University Grant Commission, Kathmandu, 2004. 
